\title{
Quantitative and Qualitative Studies of Aeromonas salmonicida Bacteriophage
}

\author{
By C. J. RODGERS, J. H. PRINGLE, † D. H. MCCARTHY $\ddagger$ AND \\ B. AUSTIN* \\ Ministry of Agriculture, Fisheries and Food, Directorate of Fisheries Research, \\ Fish Diseases Laboratory, The Nothe, Weymouth, Dorset DT4 8UB, U.K.
}

(Received 12 December 1980; revised 4 February 1981)

\begin{abstract}
A comprehensive bacteriophage typing scheme for Aeromonas salmonicida, the causal agent of furunculosis in fish, is described. It distinguishes 27 bacterial groups based on sensitivity patterns to 18 bacteriophage isolates. In addition, the sensitivity patterns are shown to reflect the morphological characteristics of the host bacterium. The 'rough', 'smooth' and 'G-phase' forms possess different quantities of lipopolysaccharide in the cell wall and this influences bacteriophage attachment. The problems related to these morphological variations are discussed.
\end{abstract}

\section{INTRODUCTION}

The effectiveness of bacteriophage typing systems has been proved by the valuable information gained in epidemiological investigations of human pathogenic bacteria, e.g. Salmonella (Boyd et al., 1951; Anderson, 1964; Gershman, 1976), Shigella (Pruneda \& Farmer, 1977) and Staphylococcus (Asheshov, 1967). Moreover, the potential application of bacteriophage typing to fish pathogens, in particular Aeromonas salmonicida, the causal agent of furunculosis, has been indicated by the work of Paterson et al. (1969) and Popoff (1971). It is essential to locate the source of infection if meaningful control measures are to be adopted. However, all too often when furunculosis is diagnosed, mismanagement or the presence of carrier fish in farm stocks or wild populations is assumed to be the origin of the disease outbreak (McCarthy, 1978).

It has been recognized that $A$. salmonicida displays morphological variation in vitro insofar as the colonies may appear as 'rough', 'smooth' or 'intermediate' (G-phase) (Duff, 1937, 1939; McCarthy \& Rawle, 1975) and much contention has centred around which of these forms is the most virulent. McCarthy (1978) found that the majority of strains from 'explosive' outbreaks exhibited a rough appearance, but Anderson (1972) reported that the virulent forms were predominantly smooth. The morphological appearance coincides with the quantity of lipopolysaccharide (LPS) in the cell wall (Anderson, 1972). However, the influence of LPS, or other cell wall components, on bacteriophage attachment and subsequent lysis of the host bacterium has not been determined. Indeed, the role of LPS in influencing bacteriophage groupings has not been considered.

Thus, to achieve an effective knowledge of the epidemiology of $A$. salmonicida infections, we have established a comprehensive bacteriophage typing scheme, thereby extending the earlier work of Paterson et al. (1969) and Popoff (1971). We have also examined the role of LPS in bacteriophage attachment.

† Present address: Department of Environmental Sciences, University of Warwick, Coventry CV4 7AL, U.K.

$\ddagger$ Present address: Tavolek Laboratories Inc, 2779 152nd Avenue, N.E., Redmond, Washington 98052, U.S.A. 
Table 1. Aeromonas strains studied

Laboratory Strain designation/ reference no. source*

Aeromonas dourgesi

147/70 NCMB 1861

$\begin{aligned} \text { Aeromonas } & \text { hydrophila } \\ 7 / 67 & \text { NCMB 89 } \\ 15 / 67 & \text { G. L. Bullock } \\ 20 / 67 & \text { NCMB 1135 } \\ 24 / 67 & \text { Laboratory isolate } \\ 33 / 67 & \text { Laboratory isolate } \\ 19 / 70 & \text { B. P. Eddy } \\ 66 / 70 & \text { Laboratory isolate } \\ 79 / 70 & \text { Laboratory isolate } \\ 103 / 70 & \text { E.F.D.L. } \\ 14 / 72 & \text { Laboratory isolate } \\ 37 / 75 & \text { Laboratory isolate }\end{aligned}$

Aeromonas liquefaciens $3 / 67 \quad$ NCTC 9747

Aeromonas punctata subsp. caviae 93/70 NCIB 9234 $94 / 70$ NCIB 9671

Aeromonas salmonicida

21/67 NCMB 833

130/68 Laboratory isolate

$3 / 69$ Laboratory isolate

91/70 NCMB 1109

$120 / 70$ Laboratory isolate

121/70 Laboratory isolate

$131 / 70$ Laboratory isolate

135/70 Laboratory isolate

143/70 NCMB 1110

$144 / 70$ Laboratory isolate

$21 / 71$ R. H. W. Schubert

$26 / 71$ Laboratory isolate

9/72 Laboratory isolate

10/72 Laboratory isolate

$15 / 72$ N.R.C

16/72 W.F.D.L.

17/72 W.F.D.L.

18/72 W.F.D.L.

$7 / 73$ T. Kimura

13/73 Laboratory isolate

$16 / 75$ Laboratory isolate

$18 / 75$ Laboratory isolate

$28 / 75$ Laboratory isolate

32/75 R. Bootsma

34/75 R. Bootsma

1/76 Laboratory isolate

2/76 Laboratory isolate

3/76 Laboratory isolate

10/76 W. D. Paterson

16/76 I. W. Smith

19/76 Laboratory isolate

20/76 Laboratory isolate

24/76 Laboratory isolate

26/76 Laboratory isolate

29/76 T. Hastein

43/76 Laboratory isolate

49/76 Laboratory isolate
Source of isolate

Bacteriophage

typing group

(U.S.A.)

Salmo gairdneri

(U.K.)

(U.K.)

-

$-$

$-$

Rutilus rutilus (U.K.)

Cyprinus carpio (U.K.)

Salvelinus fontinalis

Salmo trutta (U.K.)

Esox lucius (U.K.)

Salmo trutta (U.K.)

Tinca tinca (U.K.)

Tinca tinca (U.K.)

Salmo salar (U.K.)

Salmo gairdneri (U.K.)

Salmo trutta (U.K.)

Salmo trutta (U.K.)

Oncorhynchus sp.

Salmo trutta (U.K.)

Blicca bjoerkna (U.K.)

Salmo trutta (U.K.)

A naplopoma fimbria

Salmo clarki (U.S.A.)

Oncorhynchus kisutch (U.S.A.)

Oncorhynchus kisutch (U.S.A.)

Oncorhynchus sp. (Japan)

Salmo namaylush (Finland)

Rutilus rutilus (U.K.)

Rutilus rutilus (U.K.)

Salmo trutta (U.K.)

Cyprinus carpio (Netherlands)

Cyprinus carpio (Netherlands)

Blicca bjoerkna (U.K.)

Blicca bjoerkna (U.K.)

Blicca bjoerkna (U.K.)

(Canada)

Salmo cordinius (U.K.)

Salmo trutta (U.K.)

Salmo trutta (U.K.)

Salmo trutta (U.K.)

Salmo trutta (U.K.)

Salmo salar (Norway)

Salmo trutta (U.K.)

Salmo trutta (U.K.)
10

26

10

$1,10 \dagger$

7

$1,7+$

10

$1,2 \dagger$

10

1

13

7

11

1

$1,2+$

10

1

11

15

15

18

18

17

14

13

1

13

3

3

2

2

25

2

4 
Table 1. (continued)

Laboratory Strain designation/ reference no. source*

Aeromonas salmonicida-continued

$50 / 76$ Laboratory isolate

62/76 T. Kimura

68/76 Laboratory isolate

69/76 Laboratory isolate

70/76 Laboratory isolate

71/76 R. Sweeting

$78 / 76$ M. Popoff

$79 / 76 \quad$ M. Popoff

80/76 M. Popoff

81/76. M. Popoff

82/76 M. Popoff

84/76 M. Popoff

$85 / 76$ M. Popoff

89/76 Laboratory isolate

90/76 T. Hastein

91/76 T. Hastein

92/76 T. Hastein

93/76 T. Hastein

103/76 P. de Kinkelin

111/76 T. Hastein

125/76 T. Hastein

126/76 T. Hastein

$127 / 76 \quad$ M. Popoff

128/76 M. Popoff

129/76 M. Popoff

133/76 Laboratory isolate

170/76 R. W. Gould

175/76 Laboratory isolate

$178 / 76$

$181 / 76$

$1 / 77$

$50 / 77$

$51 / 77$

$52 / 77$

$53 / 77$

$64 / 77$

$65 / 77$

$66 / 77$

$67 / 77$

$70 / 77$

$75 / 77$

$77 / 77$

$78 / 77$

$82 / 77$

$83 / 77$

$84 / 77$

$85 / 77$

$86 / 77$

$87 / 77$

$88 / 77$

$89 / 77$

$91 / 77$

$92 / 77$

$121 / 77$

$123 / 77$

$3 / 78$
Source of isolate

Bacteriophage

typing group
Salmo trutta (U.K.)

Oncorhynchus masou (Japan)

Salmo trutta (U.K.)

Salmo trutta (U.K.)

Salmo trutta (U.K.)

Salmo trutta (U.K.)

Salmo gairdneri (France)

Salmo gairdneri (France)

Salmo gairdneri (Switzerland)

(Norway)

Salmo gairdneri (Denmark)

(Japan)

Salmo gairdneri (France)

Salmo trutta (U.K.)

Salmo salar (Norway)

Salmo salar (Norway)

Salmo salar (Norway)

Salmo salar (Norway)

Salmo gairdneri (France)

Salvelinus alpinus (Norway)

Phoxinus phoxinus (Norway)

Salmo trutta (Norway)

Salmo gairdneri (France)

(Austria)

(U.S.A.)

(Denmark)

Carassius auratus (U.S.A.)

(France)

Salmo trutta (Sweden)

Salmo gairdneri (Italy)

Salmo salar (U.S.A.)

Salmo trutta (U.K.)

Salmo trutta (U.K.)

Salmo trutta (U.K.)

Salmo trutta (U.K.)

Salmo trutta (U.K.)

Salmo trutta (U.K.)

Salmo trutta (U.K.)

Salmo trutta (U.K.)

Salmo trutta (U.K.)

Salmo trutta (U.K.)

Salmo trutta (U.K.)

Salmo trutta (U.K.)

Salmo trutta (U.K.)

Salmo trutta (U.K.)

Salmo trutta (U.K.)

Salmo trutta (U.K.)

Salmo trutta (U.K.)

Salmo trutta (U.K.)

Salmo trutta (U.K.)

Salmo trutta (U.K.)

Perca fluviatilis (U.K.)

Cyprinus carpio (U.K.)

Salmo trutta (U.K.)

Salmo trutta (U.K.)

Rutilus rutilus (U.K.)
10

2

2

1

6

1

2

1

23

24

27

27

9

22

15

20

1

19

2

4

2

2

2

2

1

10

2

10

10

$14,16^{\dagger}$

21

2

1

26

Aeromonas sobriae

5/77 M. Popoff

6/77 M. Popoff

(France)

(France) 
Table 1. (continued)

\begin{tabular}{cll}
$\begin{array}{c}\text { Laboratory } \\
\text { reference no. }\end{array}$ & $\begin{array}{c}\text { Strain designation/ } \\
\text { source* }\end{array}$ & \multicolumn{1}{c}{ Source of isolate } \\
Aeromonas spp. & \\
$6 / 69$ & - & Salmo salar (Ireland) \\
$11 / 69$ & Laboratory isolate & Cyprinus carpio (U.K.) \\
$15 / 69$ & Laboratory isolate & Salmo salar (U.K.) \\
$35 / 70$ & B. P. Eddy & - \\
$90 / 70$ & NCMB 86 & - \\
$110 / 70$ & G. L. Gilardi & (U.S.A.) \\
$33 / 71$ & Laboratory isolate & (U.K.) \\
$10 / 73$ & Laboratory isolate & Perca fluviatilis (U.K.) \\
$55 / 77$ & N. J. Jensen & (Denmark) \\
$142 / 77$ & Laboratory isolate & Blicca bjoerkna (U.K.)
\end{tabular}

Bacteriophage typing group

* Sources: E.F.D.L., Eastern Fish Diseases Laboratory, Kearneysville, West Virginia, U.S.A.; NCIB, National Collection of Industrial Bacteria, Aberdeen, Scotland; NCMB, National Collection of Marine Bacteria, Aberdeen, Scotland; NCTC, National Collection of Type Cultures, Colindale, London; N.R.C., National Research Council, Ottawa, Ontario, Canada; W.F.D.L., Western Fish Diseases Laboratory, Seattle, Washington, U.S.A.; Dr R. Bootsma, Department of Special Animal Pathology, University of Utrecht, The Netherlands; Dr G. L. Bullock, Eastern Fish Diseases Laboratory, Kearneysville, West Virginia, U.S.A.; Dr B. P. Eddy (deceased), Low Temperature Research Station, Cambridge, U.K.; Dr G. L. Gilardi, Mount Sinai Hospital, New York, U.S.A.; Dr G. Giorgetti, Istituto Zooprofilattico Sperimentale della Venezie, Italy; Dr R. W. Gould, Tavolek Inc., Redmond, Washington, U.S.A.; Dr T. Hastein, National Veterinary Institute, Oslo, Norway: Dr N. J. Jensen, Royal Veterinary and Agricultural College, Copenhagen, Denmark; Professor T. Kimura, Laboratory of Microbiology, Hokkaido University, Hakodate, Japan; Dr P. de Kinkelin, Laboratoire d'Ichtyopathologie, Institut National de la Recherche Agronomique, Paris, France; Dr O. Ljunberg, National Veterinary Institute, Stockholm, Sweden; Dr T. Needham, Unilever Research Laboratory, Aberdeen, Scotland; Dr W. D. Paterson, Environment Canada, Halifax Laboratory, Halifax, Canada; Dr M. Popoff, Institut Pasteur, Paris, France; Professor R. H. W. Schubert, Abteilung für Allgemeine und Umwelthygiene, Frankfurt, Germany; Dr I. W. Smith, Department of Bacteriology, University of Edinburgh, Scotland; Dr R. Sweeting, Thames Water Authority, Reading, Berkshire.

† Smooth and rough colony variants were recovered in different bacteriophage typing groups.

\section{METHODS}

Bacteria. The sources of the 1 strain of Aeromonas dourgesi, 11 strains of $A$. hydrophila, 2 strains of $A$. punctata subsp. caviae, 93 strains of $A$. salmonicida, 2 strains of $A$. sobriae and 10 strains of Aeromonas spp. are shown in Table 1. The strains were maintained at $4^{\circ} \mathrm{C}$ on slopes of tryptone soya agar (TSA; Oxoid). Subculturing was necessary every 6 months.

Bacteriophage. Water and effluent samples, collected from seven fish farms, five rivers and two reservoirs in England and Wales, and one effluent sample sent from a goldfish farm in Australia, were examined for the presence of bacteriophage to $A$. salmonicida. Methods for the isolation, propagation and induction of temperate bacteriophage, bacteriophage typing and lysotyping have been described elsewhere (Paterson et al., 1969; Popoff, 1971). Additional bacteriophage isolates were received from Professor M. Popoff (France) and Dr W. D. Paterson (Canada). Details of all the bacteriophage are given in Table 2.

Lipopolysaccharides. Cell wall LPS of rough and smooth strains was extracted and purified using the hot phenol technique outlined by Shaw \& Hodder (1978). A modified technique, using $0.5 \%(\mathrm{w} / \mathrm{v}) \mathrm{MgCl}_{2}$ to precipitate LPS, was necessary for G-phase cells.

Inactivation of bacteriophage by lipopolysaccharide. The amount of LPS capable of inhibiting plaque formation by bacteriophage was assessed as described by Adams (1959).

Antisera. Antisera to A. salmonicida were produced in female New Zealand white rabbits as described by McCarthy \& Rawle (1975).

Agglutination reactions. The indirect agglutination method of Hansen \& Lingg (1976) was used to characterize soluble antigen. This method involved the use of latex particles (Difco; $0.8 \mu \mathrm{m}$ diam.) suspended in phosphate-buffered saline (Dulbecco ' $\mathrm{A}$ '; Oxoid) and sensitized with an equal volume of antigen for $1 \mathrm{~h}$ at $37^{\circ} \mathrm{C}$. Sensitized latex particles were coated with $1 \%(\mathrm{w} / \mathrm{v})$ bovine serum albumin (Koch-Light) to prevent non-specific agglutination.

Equal volumes of sensitized latex particles $(50 \mu \mathrm{l})$ and antisera, containing $200 \mathrm{mg}$ polyvinylpyrrolidone $\mathrm{1}^{-1}$ (BDH), were pipetted into micro-titre trays (Cooke, Billingshurst, Sussex) (Bereks \& Querforth, 1971). Doubling dilutions were prepared to 1:65536 using phosphate-buffered saline. These were thoroughly mixed by shaking for 


\section{Table 2. Details of bacteriophage isolates}

Laboratory
reference no.

$\begin{array}{cl}\text { A } & \text { Fish farm effluent (U.K.) } \\ \text { B } & \text { Fish farm effluent (U.K.) } \\ \text { C } & \text { Reservoir (U.K.) } \\ \text { D } & \text { Fish farm effluent (Australia) } \\ \text { E } & \text { Fish farm effluent (Canada; W. D. Paterson) } \\ \text { F } & \text { Fish farm effluent (U.K.) } \\ \text { G } & \text { Fish farm effluent (U.K.) } \\ \text { H } & \text { Fish farm effluent (U.K.) } \\ \text { I } & \text { Fish farm effluent (U.K.) } \\ \text { J } & \text { Fish farm effluent (U.K.) } \\ \text { K } & \text { Fish farm effluent (U.K.) } \\ \text { L } & \text { Fish farm effluent (U.K.) } \\ \text { M } & \text { Fish farm effluent (France; M. Popoff) } \\ \text { N } & \text { Fish farm effluent (France; M. Popoff) } \\ \text { O } & \text { Fish farm effluent (France; M. Popoff) } \\ \text { P } & \text { Reservoir (France; M. Popoff) } \\ \text { Q } & \text { Reservoir (France; M. Popoff) } \\ \text { R } & \text { Reservoir (France; M. Popoff) }\end{array}$

\section{Comment}

Virulent

Virulent

Virulent

Virulent

Virulent

Virulent

Temperate

Temperate

Temperate

Temperate

Temperate

Temperate

Virulent

Temperate; u.v.-induced

Virulent

Virulent

Virulent

Virulent

* Sources: Dr W. D. Paterson, Environment Canada, Halifax Laboratory, Halifax, Canada; Dr M. Popoff, Institut Pasteur, Paris, France.

$10 \mathrm{~min}$ at $20^{\circ} \mathrm{C}$ on an oscillating plate (Luckham, London). Following overnight incubation at room temperature, the micro-titre trays were shaken to resuspend the contents, and agglutination was observed through a binocular microscope.

Electron microscopy. Cultures of $A$. salmonicida grown overnight at $26^{\circ} \mathrm{C}$ in tryptone soya broth (Oxoid) were inoculated with high-titre bacteriophage suspension. After incubation at room temperature for $30 \mathrm{~min}$, the cultures were centrifuged at low speed $\left(750 \mathrm{rev} . \mathrm{min}^{-1} ; 10 \mathrm{~min}\right.$ ) and the deposited cells were washed in phosphate-buffered saline.

Washed cells were double-fixed in glutaraldehyde $(4 \%, v / v)$ and osmium tetroxide (1\%, w/v) (Millonig, 1961) and dehydrated by serial transfer through graded ethanol solutions. Following embedding in epoxy resin adhesive (Äraldite; Ciba-Geigy) (Luft, 1961) and curing at $60^{\circ} \mathrm{C}$ for $72 \mathrm{~h}$, they were sectioned on a Reichert OMU3 ultramicrotome. Ultra-thin sections were double-stained with uranyl acetate (Watson, 1958) and lead citrate (Reynolds, 1963) and studied in a JEOL $100 \mathrm{CX}$ transmission electron microscope.

For scanning electron microscopy, washed cell suspensions were fixed in osmium tetroxide for $1 \mathrm{~h}$, washed with buffer, dehydrated by serial transfer through graded ethanol solutions and dried in a Polaron critical point drying apparatus. The dried material was mounted on stubs, coated with gold on a Polaron sputter coater and examined in a JEOL $100 \mathrm{CX}$ Temscan electron microscope.

Pathogenicity for fish. Five 6-month-old brown trout (Salmo trutta) were each injected intramuscularly with $1 \mathrm{ml}$ of washed cell suspension, containing about $10^{8}$ cells $\mathrm{m}^{-1}$. Strains of $A$. salmonicida in rough, smooth and G-phase forms were examined. The fish were maintained in fibre-glass tanks containing 151 of circulating, oxygenated fresh water at $16^{\circ} \mathrm{C}$. Feeding was not carried out during the course of these experiments. All fish were examined daily, for up to a maximum of $14 \mathrm{~d}$. Dead fish were removed and subjected to post-mortem examination. Samples of kidney, spleen, and muscle from the injection site were removed aseptically and plated on to TSA. Following incubation of these plates at $22^{\circ} \mathrm{C}$ for $72 \mathrm{~h}$, colonies of $A$. salmonicida were identified by a latex agglutination reaction (McCarthy, 1975 $a, b$ ) and bacteriophage sensitivity patterns were determined.

\section{RESULTS}

The 18 bacteriophage strains examined in this study were specific to Aeromonas salmonicida (Table 1). Thus, the 93 isolates of $A$. salmonicida were divided into 27 bacteriophage sensitivity groups (Table 3 ), with the majority of the isolates, totalling 57 , recovered in only three groups, namely 1,2 and 10 . These groups contained the majority of the U.K. isolates (Table 1). Indeed, there was a pronounced geographical distribution among the bacteriophage typing groups. The Scandinavian isolates were recovered exclusively in 
Table 3. Bacteriophage typing patterns for A. salmonicida strains

\begin{tabular}{|c|c|c|c|c|c|c|c|c|c|c|c|c|c|c|c|c|c|c|c|}
\hline \multirow{2}{*}{$\begin{array}{l}\text { Phage } \\
\text { typing } \\
\text { group }\end{array}$} & \multirow{2}{*}{$\begin{array}{l}\text { No. of } \\
\text { strains }\end{array}$} & \multicolumn{18}{|c|}{ Bacteriophage } \\
\hline & & A & B & $\mathrm{C}$ & D & $\mathrm{E}$ & $\mathbf{F}$ & $\mathrm{G}$ & $\mathbf{H}$ & I & $\mathbf{J}$ & K & L & $\mathbf{M}$ & $\mathbf{N}$ & $\mathrm{O}$ & $\mathbf{P}$ & $\mathrm{Q}$ & $\mathbf{R}$ \\
\hline 1 & $24^{*}$ & + & $\mathbf{v}$ & + & + & + & - & - & - & - & - & - & - & + & - & + & - & + & - \\
\hline 2 & $22^{*}$ & $\mathbf{v}$ & + & + & + & + & - & + & + & - & + & + & + & + & + & + & + & + & + \\
\hline 3 & 2 & - & + & + & + & + & - & + & + & - & + & + & + & + & + & + & - & + & + \\
\hline 4 & 3 & - & + & + & + & + & - & + & + & - & + & + & + & + & + & - & - & - & + \\
\hline 5 & 1 & - & + & + & + & + & - & + & + & - & + & + & + & + & + & + & + & - & + \\
\hline 6 & 2 & + & + & + & + & + & - & + & + & - & - & + & $\mathrm{v}$ & + & + & + & + & + & + \\
\hline 7 & $4^{*}$ & + & + & + & + & + & - & + & + & - & + & - & + & + & + & + & + & + & + \\
\hline 8 & 1 & + & + & + & + & + & - & - & + & - & - & - & + & + & + & + & - & + & + \\
\hline 9 & 2 & + & + & + & + & + & - & + & - & - & - & - & - & + & + & + & $\mathrm{v}$ & + & + \\
\hline 10 & $11^{*}$ & + & - & - & + & - & + & - & - & - & - & - & - & - & - & - & - & - & - \\
\hline 11 & 2 & + & + & - & + & $\mathbf{v}$ & + & - & - & - & - & - & - & - & - & - & - & - & - \\
\hline 12 & 1 & - & - & - & + & + & + & - & - & - & - & - & - & - & - & + & - & + & - \\
\hline 13 & 4 & - & - & + & $\mathrm{v}$ & - & - & + & + & + & + & + & + & - & + & - & + & - & + \\
\hline 14 & $2^{*}$ & - & - & - & - & - & - & + & + & + & + & + & + & + & + & - & + & - & + \\
\hline 15 & 3 & - & - & - & - & - & - & + & - & + & - & + & - & - & + & - & + & - & + \\
\hline 16 & $1^{*}$ & - & - & - & - & - & - & + & - & + & + & + & - & + & + & - & + & - & + \\
\hline 17 & 1 & - & - & - & - & - & - & + & - & + & + & + & + & - & + & - & + & - & + \\
\hline 18 & 2 & - & - & - & - & - & - & - & - & - & - & - & - & - & + & - & + & - & + \\
\hline 19 & 1 & - & + & - & + & - & - & - & - & + & - & + & - & - & - & - & - & - & + \\
\hline 20 & 1 & - & - & - & - & - & - & - & - & - & + & - & + & - & - & - & - & - & - \\
\hline 21 & 1 & - & - & - & - & - & - & - & - & + & - & - & - & - & - & - & - & - & - \\
\hline 22 & 1 & + & - & - & + & + & - & + & - & - & - & - & + & + & - & + & - & - & - \\
\hline 23 & 1 & - & - & + & + & + & - & + & - & + & - & - & + & + & - & + & - & - & - \\
\hline 24 & 1 & - & - & + & + & + & - & + & - & - & - & - & + & + & - & - & - & - & - \\
\hline 25 & 1 & + & - & - & + & + & - & + & - & - & - & - & + & + & - & + & - & + & - \\
\hline 26 & 2 & - & - & + & - & + & - & - & + & - & + & + & + & + & + & - & - & - & + \\
\hline 27 & 2 & - & - & - & - & - & - & + & - & - & - & - & + & - & - & - & - & - & - \\
\hline
\end{tabular}

+ , Lysis; -, no lysis; v, variable.

* Contains cultures with rough and smooth colonies which fall into two bacteriophage typing groups.

groups $7,12,15,20,22,23,24,25$ and 27 . Similarly, the Dutch isolates belonged in group 18. However, the pattern of lysis was sometimes affected by colony morphology, with smooth and rough types differing in their bacteriophage sensitivities. Hence, a single isolate could belong to more than one bacteriophage typing group, depending on its morphology, viz. rough or smooth (Table 1). Clearly, this is a serious problem, and therefore a detailed examination was made of the effect of colony morphology on bacteriophage sensitivity.

\section{Effect of colony morphology on bacteriophage sensitivity}

The morphological differences between smooth, rough and G-phase colonies (Fig. 1) were highlighted by examination of scanning electron micrographs of individual cells. Rough cells possessed an external granular layer (Fig. 2) which was absent in smooth cells (Fig. 3). G-phase cells appeared to have a very slight external layer (Fig. 4). Examination by transmission electron microscopy of thin sections from bacterial cells confirmed the presence of an extra layer around rough cells (Fig. 5), which was absent from smooth and G-phase cells (Figs 6, 7). The influence of these surface layers on bacteriophage attachment and subsequent lysis of the host cell was illustrated by the role of bacteriophage $\mathrm{F}$ and $\mathrm{N}$, which were specific and lysed only G-phase cells and rough cells, respectively. In the small-scale pathogenicity experiments, rough cells were pathogenic to Salmo trutta, while smooth cells were less pathogenic and G-phase cells were completely avirulent. 

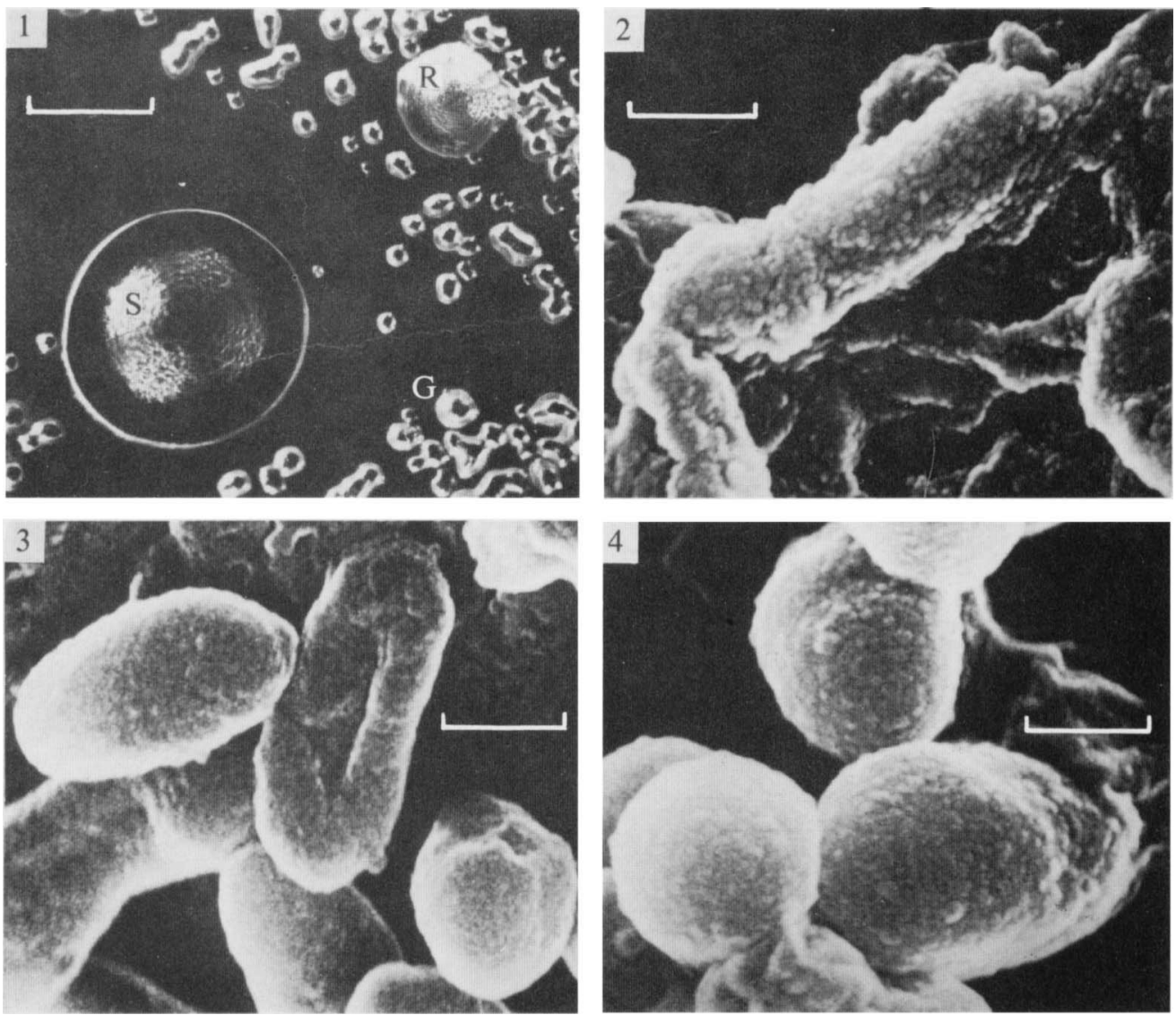

Fig. 1. Morphology of rough (R), smooth (S) and G-phase (G) colonies of Aeromonas salmonicida. The bar marker represents $1 \mathrm{~mm}$.

Figs 2-4. Scanning electron micrographs of rough cells (Fig. 2), smooth cells (Fig. 3) and G-phase cells (Fig. 4) of $A$. salmonicida. The bar markers represent $0.5 \mu \mathrm{m}$.

\section{Lipopolysaccharide}

Rough cells were rich in LPS: rough colonies of isolate $50 / 77$ yielded about $2.4 \%$ cell weight of LPS compared with only $1.4 \%$ LPS in smooth cells of the same isolate. The importance of LPS in the processes leading to viral infection was indicated by the observation that LPS extracted from rough, smooth and G-phase cells inhibited the cycle of bacteriophage replication. However, it is noteworthy that there were marked differences between the morphological forms in the quantities of LPS needed to inactivate $50 \%$ of the bacteriophage. Thus, plaque formation by bacteriophage $\mathrm{N}$, specific to rough cells of isolate $50 / 77$, was inhibited by a small quantity of LPS extracted from the host cells (Table 4), but large quantities of the same LPS were needed to affect bacteriophage F, specific to G-phase cells. With bacteriophage $\mathrm{C}$, which lyses rough and smooth cells but not $\mathrm{G}$-phase cells, plaque formation was inhibited by small amounts of LPS from rough or smooth cells.

The antigenicity of LPS was confirmed by agglutination. Purified LPS extracted from rough cells of isolate $50 / 77$ gave a higher titre $(1: 1024)$ with the homologous antiserum than that from the corresponding smooth cells $(1: 128)$. Furthermore, these serological reactions were non-specific, insofar as there was cross-agglutination with antisera prepared against smooth cells of $16 / 72$ and rough cells of $17 / 72$. Nevertheless, the titres were substantially lower than those for whole cells. 

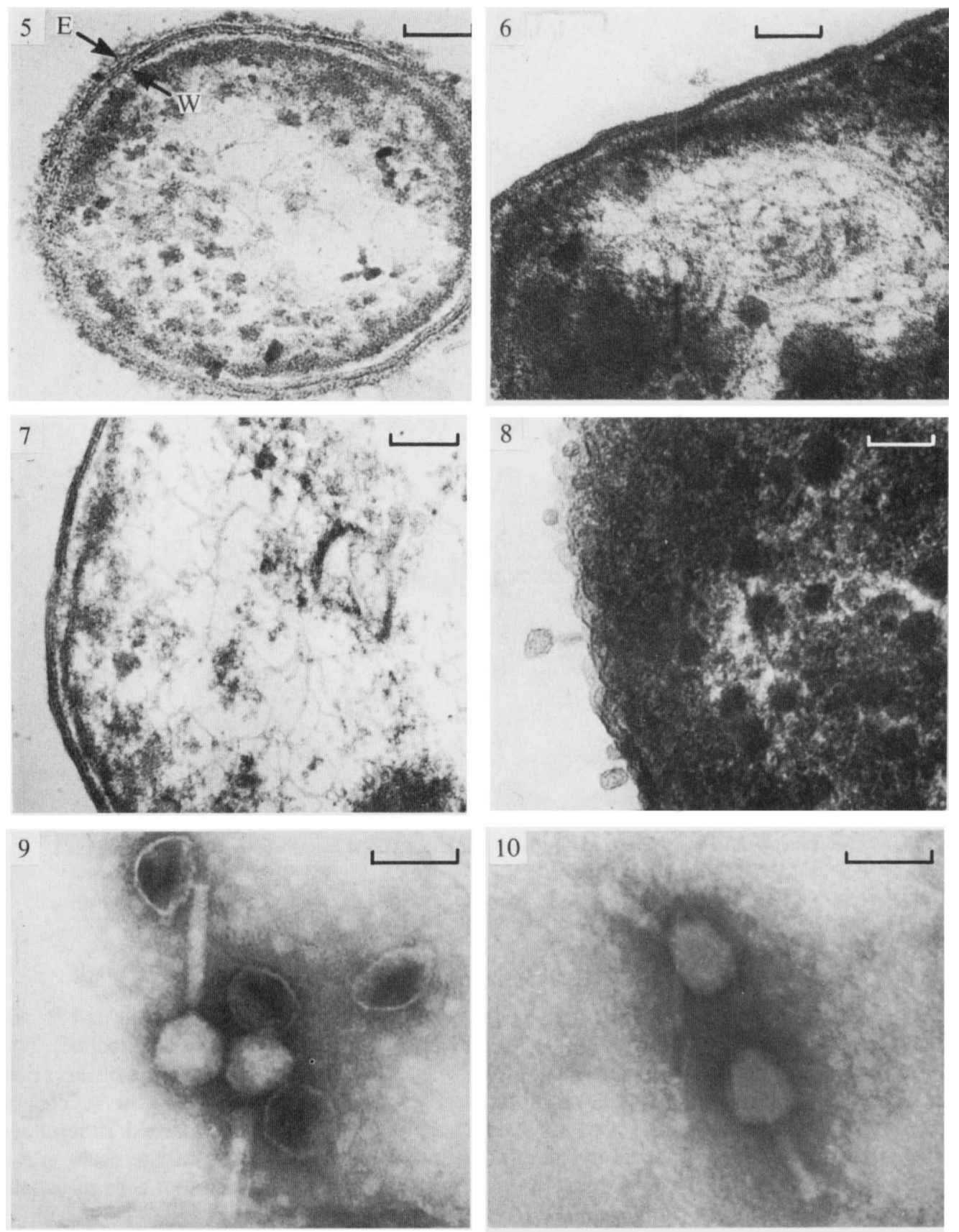

Figs 5-7. Transmission electron micrographs of thin sections through a rough cell (Fig. 5), a smooth cell (Fig. 6) and a G-phase cell (Fig. 7) of $A$. salmonicida. The rough cell shows the presence of an extra layer (E) around the cell wall (W); the smooth and G-phase cells lack an extracellular deposit. The bar markers represent $200 \mathrm{~nm}$.

Fig. 8. Thin section through a rough cell experimentally infected with bacteriophage, showing the presence of virus particles attached to the surface of the host bacterium. The bar marker represents 200 nm.

Fig. 9. Negatively-stained preparation of temperate bacteriophage $\mathrm{N}$, showing a hexagonal head and long tail. The bar marker represents $100 \mathrm{~nm}$.

Fig. 10. Negatively-stained preparation of virulent bacteriophage F. The bar marker represents $50 \mathrm{~nm}$. 
Table 4. Quantities of purified LPS from different morphological forms of isolate 50/77 needed to inhibit plaque formation by bacteriophage $C, F$ and $N$

\begin{tabular}{|c|c|c|c|}
\hline \multirow[b]{2}{*}{$\begin{array}{c}\text { Source of } \\
\text { LPS }\end{array}$} & \multicolumn{3}{|c|}{ Amount of LPS ( $\mu \mathrm{g}$ hexose) } \\
\hline & C & $\begin{array}{c}\text { cteriopha } \\
\text { F }\end{array}$ & $\mathrm{N}$ \\
\hline $\begin{array}{l}\text { Smooth } \\
\text { Rough } \\
\text { G-phase }\end{array}$ & $\begin{array}{c}0.0024 \\
0.0024 \\
>1000\end{array}$ & $\begin{array}{c}>1000^{*} \\
>1000 \\
0.28\end{array}$ & $\begin{array}{c}>1000 \\
0.009 \\
>1000\end{array}$ \\
\hline
\end{tabular}

\section{Bacteriophage}

Free bacteriophage were released into the aqueous media, following initial attachment to the specific bacterial cell (Fig. 8), penetration and replication. The morphology of the free virions, as examined by transmission electron microscopy, comprised icosahedral heads and contractile tails (Figs 9, 10). Attachment fibres were not observed.

\section{DISCUSSION}

With 18 bacteriophage strains specific to $A$. salmonicida, and corresponding to the T-even morphology type of Paterson et al. (1969), a comprehensive typing scheme was devised which should be of value in epidemiological and ecological studies. The scheme has extended the work of Popoff (1971), who described only 14 'lysotypes' of $A$. salmonicida with 8 bacteriophage strains, and highlighted some of the hitherto unassociated problems that cell morphology confers on bacteriophage sensitivity patterns. LPS, considered primarily as an endotoxin of $A$. salmonicida (Ross, 1966; Anderson, 1973; Paterson \& Fryer, 1974), was shown to be important in the infection processes, with the LPS-rich rough cells isolated most commonly from epizootics (Popoff \& Vieu, 1970; McCarthy, 1978) and found in this study to be the most pathogenic form of the organism for Salmo trutta. However, it has been shown that small numbers of smooth colony types may be isolated on TSA along with the numerically dominant rough colonies from diseased fish (C. Rodgers, unpublished data). The significance of these observations is not known at present.

The results of phage typing, LPS extraction, serological studies and electron microscopy show there are differences in outer membrane and surface LPS characteristics between the rough, smooth and G-phase forms of $A$. salmonicida. With phage receptors located in the LPS cell fractions (Lindberg, 1973, 1977), the results show that the three morphological forms have different amounts of surface LPS which lead to differences in phage typing patterns and the difficulty experienced in extracting LPS from G-phase cells.

LPS from other Gram-negative bacteria (Salmonella, Shigella and Escherichia) generally consists of an $\mathrm{O}$-specific side-chain and an inner core polysaccharide covalently bound to a lipid (Kabir et al., 1978). The O-specific side-chains carry the serological specificity of each LPS and the sequence of carbohydrate molecules in this region is species specific, with the core polysaccharide being group specific (Kabir et al., 1978).

Further work on the biochemical nature of $A$. salmonicida LPS would need to be undertaken to show whether or not fractions from the different morphological forms differ because of loss of polysaccharide side-chains, leaving an inner core region. In fact, the LPS inner core region, composed of 2-keto-3-deoxyoctonic acid (KDO) and lipid A, differs between $A$. hydrophila subsp. liquefaciens and $A$. hydrophila subsp. punctata (Ellwood, 1970). It would be interesting to know if the same is true between $A$. hydrophila and $A$. salmonicida or even between different strains of $A$. salmonicida, and whether any difference in composition between rough, smooth, G-phase and atypical strains corresponds to differences in phage attachment and typing patterns. 
The biochemical nature of Aeromonas LPS remains largely unknown, but if the LPS layers lose side-chain units then it follows that, with phage receptors in the LPS, different phage typing patterns would be inevitable with typical and atypical strains of $A$. salmonicida possessing various ratios of outer side-chain units to inner core KDO-lipid A regions. Both scanning and transmission electron micrographs confirm that the surface characteristics of the three morphological forms are quite distinct.

Despite widespread interest in furunculosis, the ecology of $A$. salmonicida has been neglected, and the natural reservoir of the organism has not been established, although the involvement of carrier fish in native populations has been tentatively suggested (McCarthy, 1978). It could be argued that the presence, and hence isolation, of bacteriophage implies the presence of the host bacterium. This has been suggested by Zachary's work with Vibrio natriegens (Zachary, 1978), but the question of how long the virus particles remain viable in the aquatic environment remains unanswered. This would be an important consideration if bacteriophage were to be exploited in meaningful ecological studies.

The role of bacteriophage typing in bacterial taxonomy should be treated cautiously, although the technique has provided useful information in identification. For example, Evelyn (1971) isolated a bacterial culture from marine sablefish which was susceptible to $A$. salmonicida bacteriophage. This information formed a useful pointer in the identification of environmental isolates. However, the problem of varying sensitivity to bacteriophage between rough and smooth cells, ignored to date, could result in mis-identification.

In conclusion, the comprehensive bacteriophage typing system for $A$. salmonicida described in this study should prove useful in epidemiological and ecological studies providing the shortcomings, i.e. different sensitivity patterns between rough, smooth and G-phase cells of the same strain, are recognized.

\section{REF E RE NCES}

ADAMS, M. H. (1959). Bacteriophages. New York: Interscience.

ANDERSON, E. S. (1964). Phage typing of Salmonella other than $S$. typhi. In The World Problem of Salmonellosis, pp. 89-110. Edited by Van Oye. The Hague: W. Junk.

ANDERSON, D. P. (1972). Virulence and persistence of rough and smooth forms of Aeromonas salmonicida inoculated into Coho salmon (Oncorhynchus kisutch). Journal of the Fisheries Research Board of Canada 29, 204-206.

ANDERSON, D. P. (1973). Investigations of the lipopolysaccharide fractions from Aeromonas salmonicida smooth and rough forms. In Symposium on the Major Communicable Fish Diseases in Europe and their Control, pp. 175-179. Rome: Food and Agriculture Organization of the United Nations.

Asheshov, E. H. (1967). Bacteriophage typing of staphylococci. In Progress in Microbiological Techniques, pp. 173-183. Edited by C. H. Collins. London; Butterworths.

BEREKS, R. \& QUERForTh, G. (1971). The use of the latex test for the detection of distant serological relationships among plant viruses. Journal of General Virology 12, 25-32.

Boyd, J. S. J., PARker, M. T. \& MAIR, N. S. (1951). Symbiotic bacteriophage as a 'marker' in the identification of strains of Salmonella typhimurium. Journal of Hygiene 49, 442-452.

DuFf, D. C. B. (1937). Dissociation of Bacillus salmonicida with special reference to the appearance of a $\mathrm{G}$ form of culture. Journal of Bacteriology 34, 49-66.

DuFF, D. C. B. (1939). Some serological relationships of the $\mathrm{S}, \mathbf{R}$ and $\mathrm{G}$ phases of Bacillus salmonicida. Journal of Bacteriology 38, 91-100.

EllwooD, D. C. (1970). The distribution of 2-keto3-deoxy-octonic acid in bacterial walls. Journal of General Microbiology 60, 373-380.

EvelYN, T. P. T. (1971). An aberrant strain of the bacterial fish pathogen Aeromonas salmonicida isolated from a marine host, the sablefish (Anaplopoma fimbria), and from two species of cultured Pacific Salmon. Journal of the Fisheries Research Board of Canada 28, 1629-1634.

Gershman, M. (1976). Phage typing system for Salmonella enteritidis. Applied and Environmental Microbiology 32, 190-191.

Hansen, C. B. \& LiNGG, A. J. (1976). Inert particle agglutination test for the detection of antibody to enteric redmouth bacterium. Journal of the Fisheries Research Board of Canada 33, 2857-2860.

Kabir, S., Rosenstreich, D. L. \& Mergenhagen, S. E. (1978). Bacterial endotoxins and cell membranes. In Bacterial Toxins and Cell Membranes, pp. 59-87. Edited by J. Jeljaszewicz \& T. Wadström. London \& New York: Academic Press.

LINDBERG, A. A. (1973). Bacteriophage receptors. Annual Review of Microbiology 27, 205-241.

LINDBERG, A. A. (1977). Bacterial surface carbohydrates and bacteriophage adsorption. In Surface Carbohydrates of the Procaryotic Cell, pp. 289-356. 
Edited by I. W. Sutherland. London \& New York: Academic Press.

LUFT, J. H. (1961). Improvements in epoxy resin embedding methods. Journal of Biophysical and Biochemical Cytology 9, 409.

MCCARTHY, D. H. (1975a). Fish furunculosis. Journal of the Institute of Fisheries Management 6, 13-18.

MCCARThy, D. H. (1975b). Detection of Aeromonas salmonicida antigen in diseased fish tissue. Journal of General Microbiology 88, 384-386.

MCCARTHY, D. H. (1978). Some ecological aspects of the bacterial fish pathogen Aeromonas salmonicida. In Aquatic Microbiology, pp. 299-324. Edited by F. A. Skinner \& J. M. Shewan. London: Academic Press.

MCCarthy, D. H. \& RAwle, C. T. (1975). The rapid serological diagnosis of fish furunculosis caused by 'smooth' and 'rough' strains of Aeromonas salmonicida. Journal of General Microbiology 86, 185187.

Millonig, G. (1961). A modified procedure for lead staining of thin sections. Journal of Biophysical and Biochemical Cytology 11, 736.

PATERSON, W. D. \& FRYER, J. L. (1974). Effect of temperature and antigen doses on the antibody response of juvenile Coho salmon (Oncorhynchus kisutch) to Aeromonas salmonicida endotoxin. Journal of the Fisheries Research Board of Canada 31, 1743-1749.

Paterson, W. D., Douglas, R. J., Grinyer, I. \& MCDermott, L. A. (1969). Isolation and pre- liminary characterization of some Aeromonas salmonicida bacteriophages. Journal of the Fisheries Research Board of Canada 26, 629-632.

PopofF, M. (1971). Studies on Aeromonas salmonicida. II. Characterization and typing of bacteriophages that act on Aeromonas salmonicida. Annales de Recherches vétérinaires 2, 33-45.

POPOFF, M. \& VIEU, J. F. (1970). Bactériophages et lysotypie de Aeromonas salmonicida. Comptes Rendus hebdomadaire des séances de l'Académie des Sciences 270D, 2219-2222.

PrunedA, R. C. \& FARMER, J. J. (1977). Bacteriophage typing of Shigella sonnei. Journal of Clinical Microbiology 5, 66-74.

REYNOLDS, E. S. (1963). The use of lead citrate at high $\mathrm{pH}$ as an electron-opaque stain in electron microscopy. Journal of Cell Biology 17, 208-212.

Ross, A. D. (1966). Endotoxin studies. In Progress in Sport Fishery Research 1966, vol. 39. Washington: Resource Publication, Fisheries and Wildlife Service.

Shaw, D. H. \& HODDER, H. J. (1978). Lipopolysaccharides of motile aeromonads - core oligosaccharide analysis as an aid to taxonomic classification. Canadian Journal of Microbiology 24, 864-868.

Watson, M. L. (1958). Staining of tissue sections for electron microscopy with heavy metals. Journal of Biophysical and Biochemical Cytology 4, 475.

ZACHARY, A. (1978). An ecological study of bacteriophages of Vibrio natriegens. Canadian Journal of Microbiology 24, 321-324. 